\title{
A SIMULATION MODEL OF MESOPHYTIC PERENNIAL GRASSLANDS
}

\author{
Giorgio Castellaro G. ${ }^{*}$, Claudio Aguilar G. ${ }^{2}$, Raúl Vera I. ${ }^{2}$, and Luis Morales S. ${ }^{1}$
}

Grasslands are complex ecosystems and their processes are affected by soil, meteorological, and management variables. In this context, dynamic simulation models are useful to understand these processes and to design grassland use strategies. The aim of this study was to develop and validate a simulation model of perennial pasture growth based on soil and climate variables. A first approach considered that soil fertility levels were adequate; therefore, soil water availability and phytomass level were the main variables affecting pasture growth. The subroutines considered were water balance, pasture growth, and root biomass dynamics. The hypotheses regarding the functioning of the system were formulated as a group of equations which were solved numerically with a program written in Visual Basic®. Model validation was performed by statistical comparison between simulated DM and DM obtained from experiments conducted in Valdivia (39 $47^{\prime}$ S., $73^{\circ} 15^{\prime} \mathrm{W} ; 9 \mathrm{~m}$ a.s.1.). In these experiments we measured DM accumulation on naturalized grassland and ryegrass (Lolium perenne L.)-white clover (Trifolium repens L.) pastures under frequent defoliation. Soil data, temperature, solar radiation, and rainfall were obtained from a meteorological station located in Valdivia. The coefficient of determination between simulated values and those measured in the experiments were higher in the DM accumulation $\left(\mathrm{R}^{2}=98 \%\right)$ simulations When pasture was subjected to frequent defoliation, the degree of fit of the model was lower $\left(\mathrm{R}^{2}=60 \%\right)$; however, the model was able to predict the trend in the data.

Key words: Grassland simulation models, mesophytic grasslands.

$\mathrm{O}$ the total grassland area in Chile, 8.8 million ha are occupied by mesophytic grasslands (Ahumada and Faúndez, 2001), which are concentrated in the La Araucanía, Los Ríos, and Los Lagos Regions; they are the forage base for the meat and milk grazing production systems. The productivity of these grasslands is a complex process that depends on agro-ecological and management factors such as precipitation and temperature variability, soil water holding capacity, soil fertility, as well as aspects such as stocking rate and defoliation frequency. Given the complexity of these systems, simulation models appear to be an alternative to study and evaluate them. Since the late 70s grazing system simulation models have been developed at the national level (Castellaro et al., 2007; Toro et al., 2009). A common characteristic found in almost all of these systems is an underdeveloped dynamic grassland subsystem but with a robust animal subsystem conceptualization. While this has shown good results in short-term simulations, using these models can be limited when the objective is analysis over a longer period of time. This is especially true when assessing climate risk and grazing system sustainability or when the objective is modeling the same grazing system in different agro-

${ }^{1}$ Universidad de Chile, Facultad de Ciencias Agronómicas, Casilla 1004, Santiago, Chile. "Corresponding author (gicastel@uchile.cl). ${ }^{2}$ Pontificia Universidad Católica de Chile, Facultad de Agronomía e Ingeniería Forestal, Av. Vicuña Mackenna 4860, Santiago, Chile. Received: 6 December 2011

Accepted: 28 May 2012. climatic conditions where there is no empirical evidence related to grassland growth and nutritional quality. This latter component will be essential and influenced by changes in growing conditions and grazing effects. The hypothesis of this study is that a simple grassland growth model can simulate the effects of different management strategies on the dynamics of DM accumulation in mesophytic grasslands. Our objective was to develop a simulation model of water balance, pasture growth, and senescence for this type of grassland based on the simple access of soil and climatic variables.

\section{MATERIALS AND METHODS}

The first version of this model considered that soil fertility was not a limiting factor, so the climatic variables and those associated with soil water retention and biomass availability were the main influence on grassland growth. Water balance, grassland growth, and root biomass dynamics subroutines were considered. The description of the system condition was performed by state variables, which define the status of the system at any given point in time and whose size is determined by the processes establishing matter flow of or from the state variable. Material flows are controlled by state variables and exogenous variables exogenous to the system (meteorological variables) through feedback mechanisms. The hypotheses regarding system functioning were mathematically formulated, thus obtaining a system of 
equations which was numerically solved with a time step of $1 \mathrm{~d}$ and a computer program written in Visual Basic 6.0, Excel $\circledR$ interface.

Soil water balance submodel. One of the most important factors in grassland production is water availability in the root zone. In accordance with the abovementioned, we simulated the water balance in the root zone based on the cascade type model suggested by Castellaro et al. (2010), which was modified in aspects related to evapotranspiration since such a process is closely interconnected with the development and size of the photosynthesizing biomass.

Soil evaporation. The soil evaporation rate $\left(E R, \mathrm{~mm} \mathrm{~d}^{-1}\right)$ should come only from the first soil layer at a depth of 10 to $15 \mathrm{~cm}$. When the soil water content is higher than the permanent wilting point, evaporation occurs at a rate equal to potential evaporation $\left(E p, \mathrm{~mm} \mathrm{~d}^{-1}\right)$. This variable depends on the reference evapotranspiration $\left(E O, \mathrm{~mm} \mathrm{~d}^{-1}\right)$ and effective soil cover $\left(C O B_{e f}\right)$ expressed as a fraction between 0 and 1 (Rickert et al., 2000). When soil water is lower than the permanent wilting point, evaporation is reduced by the relative water content in the layer (WDIv), which is referred to as residual water content estimated at one third of the permanent wilting point (Campbell, 1997). The following equations describe the above process:

$$
\begin{gathered}
E p=E o \times\left(1-C O B_{e f}\right) \\
E R=E p \times I D H v
\end{gathered}
$$

Evapotranspiration is calculated by the PriestleyTaylor method (Moir et al., 2000; Sumner and Jacobs, 2005). Effective soil cover depends on the green $\left(C O L_{v}\right)$ and dead DM cover, including litter $\left(C O L_{m}\right)$. Variables expressed in fractional values between 0 and 1 are related to the following equations (Rickert et al., 2000):

$$
\begin{gathered}
C O L_{e f}=1-\left(1-C O L_{v}\right) \times\left(1-C O L_{m}\right) \\
C O L_{v}=1-e^{\frac{-0.69314718 \times \mathrm{GDM}}{\mathrm{GDM}_{\mathrm{cob} 50}}}
\end{gathered}
$$

where $G D M_{c o b 50}\left(\mathrm{~kg} \mathrm{ha}^{-1}\right)$ is the green dry matter $(G D M)$ producing $50 \%$ of ground cover.

$$
C O B_{m}=\frac{\text { LITTER }+ \text { DDM }}{10000}
$$

The water stress index for the evaporative process (WDIv) is calculated in accordance with the following equation (Campbell, 1997):

$$
W D I_{v}=\left(\frac{\left(S M_{i}-0.33 \times p w p_{i}\right)}{\left(p w p_{i}-0.33 \times p w p_{i}\right)}\right)^{2}
$$

where $S M_{i}(\mathrm{~mm})$ is soil moisture in the first layer and $p w p_{i}$ $(\mathrm{mm})$ is its permanent wilting point.

Grassland transpiration. Transpiration from each soil layer $\left(T E_{i}, \mathrm{~mm} \mathrm{~d}^{-1}\right)$ was simulated from the potential transpiration $\left(T P, \mathrm{~mm} \mathrm{~d}^{-1}\right)$, which is restricted by multipliers related to the degree of water restriction present in the soil layer $\left(F R T W D_{i}\right)$ (Equation [10]), by a root activity factor (Rootact) that depends on soil surface temperature (Equation [8]), and the proportion of roots in the soil layer $\left(\operatorname{Rootf}_{i}\right)$ :

$$
T S_{i}=T P \times F R T W D_{i} \times \operatorname{Rootact} \times \operatorname{Root} f_{i}
$$

Rootact only affects water absorption in the subsuperficial soil layers (Wight and Hanks, 1981) and depends on soil temperature (TMDsoil, $\left.{ }^{\circ} \mathrm{C}\right)$, which was assumed to be equal to mean air temperature $\left(T M D,{ }^{\circ} \mathrm{C}\right)$. Rootact $=1 \quad$ for superficial soil layer [8.1] Rootact $=0.071 \times T M D$ soil for subsuperficial

$$
\text { soil layers }
$$

The proportion of roots in each soil layer $\left(\right.$ Rootf $\left._{i}\right)$ is calculated in accordance with the depth of each layer by always assigning a reference value equal to unity to the relative proportion of existing roots in the surface layer.

Potential transpiration is simulated as a function of reference evapotranspiration and vegetation cover factor $\left(C O L_{V}\right)$, which in turn is a function of green DM:

$$
T P=\text { So } \times C O L_{v}
$$

The factor that reduces $T P$ depends on the available water level in the soil layer:

$$
\begin{array}{cl}
\text { FRTWH }_{i}=\frac{W D I_{i}}{W D I c r i t} & \text { if } W D I_{i}<W D I c r i t \\
\text { FRTWD }_{i}=1 & \text { if } W D I_{i} \geq W D I c r i t
\end{array}
$$

where $W D I_{i}$ is layer soil water deficit index calculated based on layer soil water level $\left(S M_{i}, \mathrm{~mm}\right)$ and layer field capacity $\left(f c_{i}, \mathrm{~mm}\right)$ and permanent wilting point $\left(p w p_{i}\right.$, $\mathrm{mm})$ :

$$
W D_{i}=\frac{(S M-p w p)_{i}}{(f c-p w p)_{i}}
$$

WDIcrit represents the soil water index value above which grassland transpiration is not restricted and indicates the degree of plant resistance to water stress. A value from 0.5 to 0.8 for this coefficient is generally accepted for grasslands (Wight and Hanks, 1981). Actual grassland transpiration $\left(T, \mathrm{~mm} \mathrm{~d}^{-1}\right)$ is calculated by adding the contributions of each of the layers:

$$
T=\sum_{i=1}^{n} \mathrm{TS}_{i}
$$

Grassland growth submodel. This submodel is the interaction between meteorological variables, soil, plants, and grazing animals. These subsystems are interconnected through key processes such as grassland growth $(T G, \mathrm{~kg}$ $\mathrm{ha}^{-1} \mathrm{~d}^{-1}$ ), grassland senescence (Tsen, $\mathrm{kg} \mathrm{ha}{ }^{-1} \mathrm{~d}^{-1}$ ), loss of dead material (TLOSSDDM, $\mathrm{kg} \mathrm{ha}^{-1} \mathrm{~d}^{-1}$ ), loss of green material by trampling (TLOSSGDM, $\mathrm{kg} \mathrm{ha}^{-1} \mathrm{~d}^{-1}$ ), and litter decomposition (TDECOMP, $\mathrm{kg} \mathrm{ha}^{-1} \mathrm{~d}^{-1}$ ). Animal selection and green $\left(G D M I, \mathrm{~kg} \mathrm{ha}^{-1} \mathrm{~d}^{-1}\right)$ and dry material (DDMI, $\mathrm{kg} \mathrm{ha}^{-1} \mathrm{~d}^{-1}$ ) intake were also considered in the case where grassland is grazed. These processes define three state variables: Green DM (GDM, kg DM ha $\left.{ }^{-1}\right)$, dead DM (DDM, DM ha-1) and litter (LITTER, $\left.\mathrm{kg} \mathrm{ha}^{-1}\right)$. Equations for these state variables are:

$G M D_{t}=G M D_{t-1}+T G-T S E N-G M D I-T L O S S G D M \quad[13]$

$D D M_{t}=D D M_{t-1}+T S E N-D D M I-T L O S S D D M$ 
$$
\text { LITTER }_{t}=\text { LITTER }_{t-1}+\text { TLOSSDDM + }
$$$$
\text { TLOSSGDM - TDECOMP }
$$

The processes and variables listed above are related to the elements indicated in the flowchart shown in Figure 1.

Grassland growth rate. The maximum grassland growth rate $\left(T G M A X, \mathrm{~kg} \mathrm{DM} \mathrm{ha}^{-1} \mathrm{~d}^{-1}\right)$ is calculated in terms of a potential grassland growth rate (TGPOT, $\mathrm{kg} \mathrm{DM} \mathrm{ha-1}$ $\left.\mathrm{d}^{-1}\right)$ and the ability of the grassland cover to intercept radiation measured by the leaf area function (LAI).

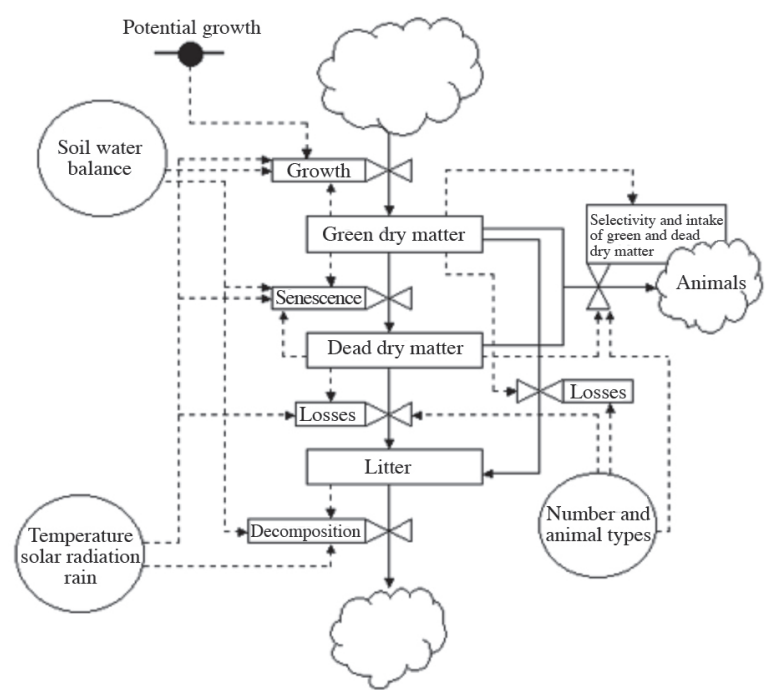

Figure 1. Simplified flow chart of growth, senescence, loss, and decay in a grazed grassland process.
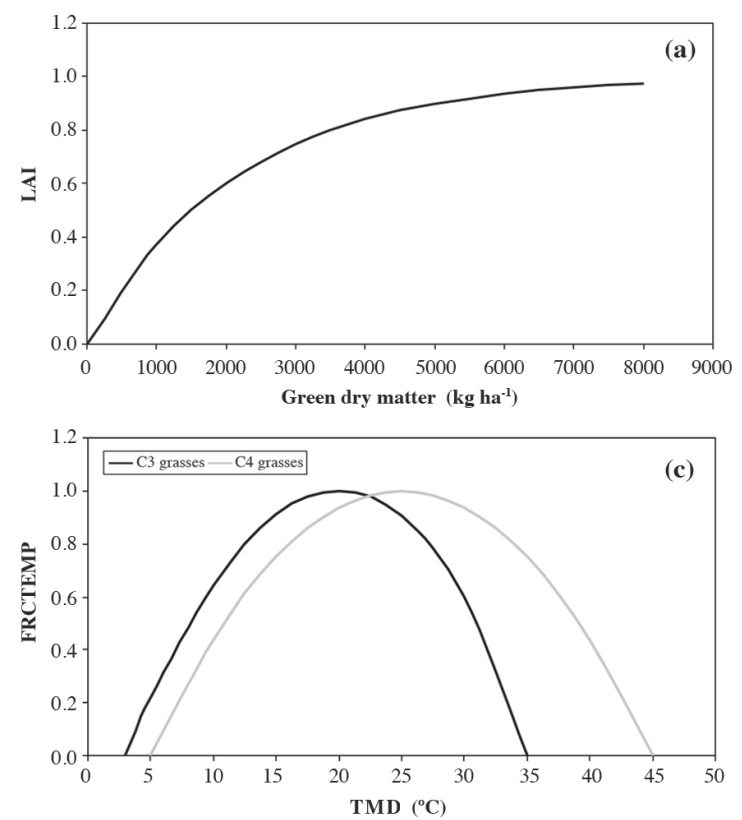

Grassland potential growth rate is a characteristic value of the particular type of grassland, which in the case of temperate grasslands has a value close to $250 \mathrm{~kg} \mathrm{DM} \mathrm{ha}^{-1}$ $\mathrm{d}^{-1}$ (Dowle and Armstrong, 1990).

$$
T G M A X=T G P O T \times L A I
$$

The leaf area function $(L A I)$ is defined by the following equation:

$$
L A I=1-\mathrm{e}^{\frac{-0.69314718 \times G D M}{G D M_{\operatorname{cob} 50}}}
$$

where $G D M_{t c p 50}$ is the grassland green $\mathrm{DM}$ at $50 \%$ potential growth rate (Figure $2 \mathrm{a}$ ).

To estimate the actual grassland growth rate $(T G, \mathrm{~kg}$ DM ha-1 $\left.\mathrm{d}^{-1}\right), T G M A X$ should be adjusted by the weighted value of three multipliers (with observed values ranging from $0-1)$, which are related to daily mean values of solar radiation $(F S R)$, mean air temperature (FRCTEMP), and degree of soil water stress (FRCWD) (Rickert et al., 2000). The resulting product, called GROWTHINDEX is further weighted by a relative factor which depends on root biomass (ROOTSCALAR) and reflects the effect of this component on the shoot biomass growth rate (Hudson et al., 2001):

\section{$T G=T G M A X \times G R O W T H I N D E X \times R O O T S C A L A R \quad[18]$ \\ GROWTHINDEX $=F S R \times F R C W D \times F R C T E M P$ [19]}

The FSR index expresses the sensitivity of grassland cover to global solar radiation levels $\left(G S R, \mathrm{MJ} \mathrm{m}^{-2} \mathrm{~d}^{-1}\right)$. This is described in Equation [20], which is similar to the results reported by Rickert et al. (2000) and shown in Figure $2 b$.

$$
F R S=1-e^{-C O E F G S R \times G S R}
$$

where COEFGSR is a coefficient that measures vegetation sensitivity to solar radiation with values equal to 0.25 and 0.10 for species with $\mathrm{C}_{3}$ and $\mathrm{C}_{4}$ photosynthetic
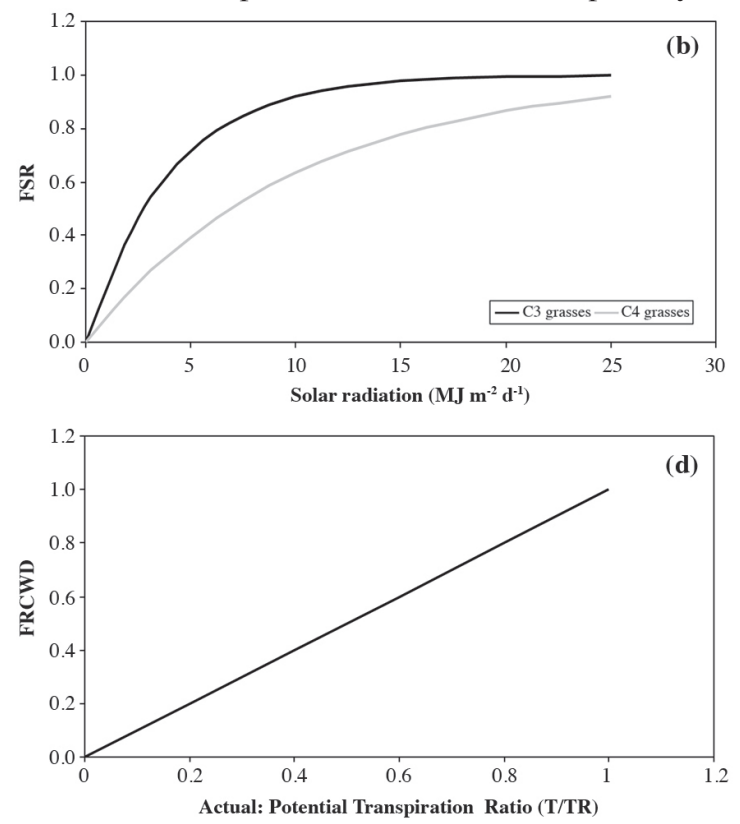

TMD: mean air temperature.

Figure 2. (a) Growth restriction function for green dry matter availability effects (LAI). (b) Growth restriction function for solar radiation effects (FSR). (c) Growth restriction function for mean air temperature effects (FRCTEMP). (d) Growth restriction function that affects the grassland growth for water deficit effects (FRCWD), as measured by the ratio between actual transpiration and grassland potential transpiration (TR/TP). 
mechanisms, respectively (Rickert et al., 2000).

The function that restricts grassland growth with temperature effects is:

$$
\text { FRCTEMP }=\alpha \times\left(T M D-T_{u}\right) \times\left(T_{\text {crit }}-T M D\right)^{\beta}
$$

where TMD is mean temperature $\left({ }^{\circ} \mathrm{C}\right)$. Coefficients $\alpha$ and $\beta$ depend on the threshold mean temperature $\left(T_{u},{ }^{\circ} \mathrm{C}\right)$ at which growth is zero, the optimum mean temperature $\left(T_{o p t},{ }^{\circ} \mathrm{C}\right)$ at which growth is maximum, and a critical mean temperature $\left(T_{\text {crit }},{ }^{\circ} \mathrm{C}\right)$ above which growth stops because of heat stress. These values are 3,20 , and $34{ }^{\circ} \mathrm{C}$ for $\mathrm{C}_{3}$ grasses and 5, 25, and $45{ }^{\circ} \mathrm{C}$ for $\mathrm{C}_{4}$ grasses (Baker and Jung, 1968; Hanson et al., 1988). This equation is shown in Figure 2c. In turn, the function that restricts growth by water stress is defined by the ratio between actual grassland transpiration, which is calculated by adding transpiration that comes from every soil layer occupied by roots (Equation [12]) and potential transpiration by using a linear equation shown in Figure 2d (Wight and Hanks, 1981; Wight et al., 1986):

$$
F R C W D=\frac{\sum_{i=1}^{n} \mathrm{TRE}_{i}}{\mathrm{TP}}
$$

Coefficients for Equations [16] to [21] are representative of a group of species and could be modified based on the group's behavior in relation to a particular growth factor. Thus, the model can be easily adapted to simulate different types of grasslands.

The effect of root biomass on grassland growth is simulated by a function (ROOTSCALAR) that depends on the grassland root system biomass (MSROOTS, $\mathrm{kg} \mathrm{ha}^{-1}$ ) and indicates the degree to which accumulated reserves in the roots affect grassland growth rate (Figure 3). The equation is based on data provided by Hudson et al. (2001) and is mathematically expressed as:

$$
\text { ROOTSCALAR }=\frac{1}{1+20.895 \times \mathrm{e}^{-0.00481 \times \mathrm{MSROOTS}}}
$$

Grassland senescence. The grassland senescence process (Tsen, $\mathrm{kg} \mathrm{DM} \mathrm{ha}^{-1} \mathrm{~d}^{-1}$ ) transforms green DM to dead DM, generating the $D D M$ level $\left(\mathrm{kg} \mathrm{ha}^{-1}\right)$. This $D D M$ level is controlled by grassland phenology (natural senescence, natsen, $\mathrm{d}^{-1}$ ) and water stress (hydric senescence, hydrsen $\left.\mathrm{d}^{-1}\right)$ (Rickert et al., 2000). Actual senescence is considered to be the sum of both types of senescence:

$$
T S E N=(\text { natsen }+ \text { hydrsen }) \times G D M
$$

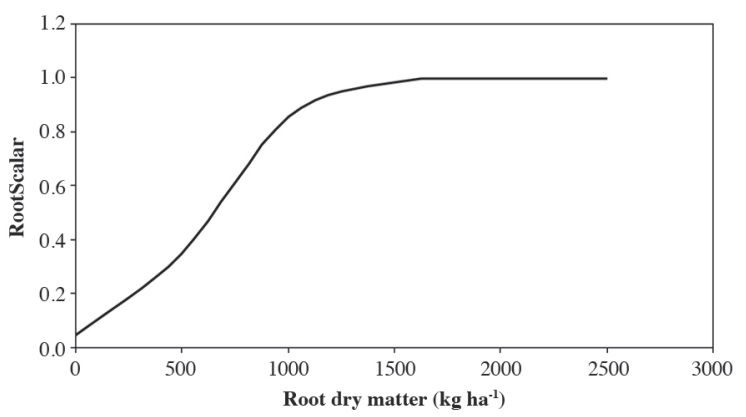

Figure 3. Function restricting grassland growth rate by root biomass effects (RootScalar).
Natural senescence is mainly due to shading effects and varies according to total grassland DM availability ( $G D M$ $\left.+D D M, \mathrm{~kg} \mathrm{ha}^{-1}\right)$. In turn, hydric senescence occurs when growth is constrained by a lack of water in the soil, which is assessed by the $F R C W D$ variable (Equation [21]). The mathematical expressions of natural senescence that are due to the water stress effects are:

$$
\begin{aligned}
\text { natsen } & =0.0015 \times e^{0.00025 \times(\mathrm{GDM}+\mathrm{DDM})} \\
\text { hydrsen } & =\text { hydrsenmax } \times(1-F R C W D)
\end{aligned}
$$

A maximum value (hydrsenmax) was estimated for hydric senescence in the order of 3\% per day (Birchman and Hodgson, 1983; van Heemst, 1986; Doyle et al., 1989; Dowle and Armstrong, 1990).

Dead material losses and trampling effects on green dry matter. Dead material losses (TLOSSDDM, $\mathrm{kg} \mathrm{ha}^{-1}$ $\mathrm{d}^{-1}$ ) involved factors associated with meteorological variables such as air temperature $\left(T M D,{ }^{\circ} \mathrm{C}\right)$ and rainfall $\left(\right.$ RAIN, $\left.\mathrm{mm} \mathrm{d}^{-1}\right)$, which define a natural loss (natloss, $\left.\mathrm{d}^{-1}\right)$. We must add the trampling effect by animals (trampling, $\left.\mathrm{d}^{-1}\right)$, which is related to the effective stocking rate (ESR, animal units $\mathrm{ha}^{-1}$ ). The above process was quantified using the equations published by Hanson et al. (1988), Blackburn and Kothmann (1989):

$$
\begin{gathered}
\text { TLOSSDDM }=(\text { natloss }+ \text { trampling }) \times D D M \\
\text { natloss }=1-e^{-0.003077 \times \mathrm{RAIN}}+0.0005 \times T M D \\
\text { trampling }=0.05 \times\left(1-e^{-0.01 \times \mathrm{ESR}}\right) \\
E S R=S R \times(\mathrm{W} / 450)^{0.75}
\end{gathered}
$$

In Equation [30], the variable $S R$ is the stocking density of a certain animal category (heads ha-1 $\mathrm{d}^{-1}$ ). The variable $W$ is the animal live weight ( $\mathrm{kg}$ ) and the coefficient " 450 " is the standard animal unit live weight (Holechek et al., 2001). These variables come into play when pasture is grazed. Because of this animals also destroy part of the grassland green DM. The amount of GDM that is lost by trampling effects (TLOSSGDM, $\mathrm{kg} \mathrm{ha}^{-1} \mathrm{~d}^{-1}$ ) is not part of the litter pool. As in the case of dead DM, GDM loss by trampling effects depend on the effective stocking rate. We therefore used the equation proposed by Hanson et al. (1988):

$$
T L O S S G D M=\left(1-e^{-0.006 \times E S R}\right) \times G D M
$$

Litter decomposition. The litter decomposition process (TDECOMP, $\mathrm{kg} \mathrm{ha}^{-1} \mathrm{~d}^{-1}$ ) depends on temperature and water conditions prevailing in the soil surface layer. As a first approach we assumed a maximum daily rate of litter loss equal to $15 \%\left(\right.$ Decmax $\left.=0.15 \mathrm{~d}^{-1}\right)$. This figure was modified according to the value of the surface layer water content index (WDIlitter) and a function that depends linearly on the temperature of this layer when it is below $18{ }^{\circ} \mathrm{C}$ (FTEMPlitter). The process is not limited above this critical temperature value (Hudson et al., 2001):

TDECOMP $=$ DECREAL $\times$ LITTER

DECREAL $=$ Dec $\max \times$ WDIlitter $\times$ FTEMPlitter [33]

$$
\text { FTEMPlitter }=\frac{T D M_{\text {soil }}}{18} \quad \text { if } T M D \text { soil }<18{ }^{\circ} \mathrm{C} \quad[34.1]
$$


Root biomass dynamics submodel. Root pool dynamics in soil is of vital importance, especially in perennial type grasslands. A lot of the net production in these ecosystems occurs under the soil surface (Smith and Smith, 2000). Roots also store carbohydrate reserves which are reused in the regrowth process and are essential to absorb water and nutrients. To the extent that the root system is vigorous, the grassland will be more resistant to defoliation effects. For these reasons there is interdependence between above-ground photosynthesizing DM and the root system. Because of this it is important to simulate root biomass dynamics and its effect on the shoot biomass growth rate. We therefore assumed the existence of a level of root biomass (MSROOTS, $\mathrm{kg} \mathrm{ha}^{-1}$ ) which is fueled by root growth (TGroots, $\mathrm{kg} \mathrm{ha}^{-1} \mathrm{~d}^{-1}$ ) and released by mortality (TMORTroots, $\mathrm{kg} \mathrm{ha}^{-1} \mathrm{~d}^{-1}$ ).

MSROOTS $_{t}=$ MSROOTS $_{t-1}+$ TGroots - TMORTroots [35]

Figure 4 shows a simplified diagram of root pool dynamics in the soil and its effect on grassland growth.

Root growth rate. Root growth rate (TGroots, $\mathrm{kg} \mathrm{ha}^{-1}$ $\mathrm{d}^{-1}$ ) is assumed to be directly proportional to the product of photosynthesized DM and the relative degree of root accumulation, which follows a sigmoid growth pattern. The equation is the one proposed by Hudson et al. (2001):

$$
\text { TGroots=reflectionfrac } \times G D M \times\left(1-\frac{M S R O O T S}{K r f}\right)
$$

where reflectionfrac is a proportionality constant with a value of 0.04 and $K r f$ is a constant coefficient equal to $6000 \mathrm{~kg} \mathrm{ha}^{-1}$.

Root mortality rate. It was assumed that root mortality rate (TMORTroots, $\mathrm{kg} \mathrm{ha}^{-1} \mathrm{~d}^{-1}$ ) only depends on root biomass and soil surface mean temperature (tmdsoilsurf, ${ }^{\circ} \mathrm{C}$ ). This variable determines the fraction of roots that die daily (mortroots, $\mathrm{d}^{-1}$ ). The equations were derived from data provided by Hudson et al. (2001):

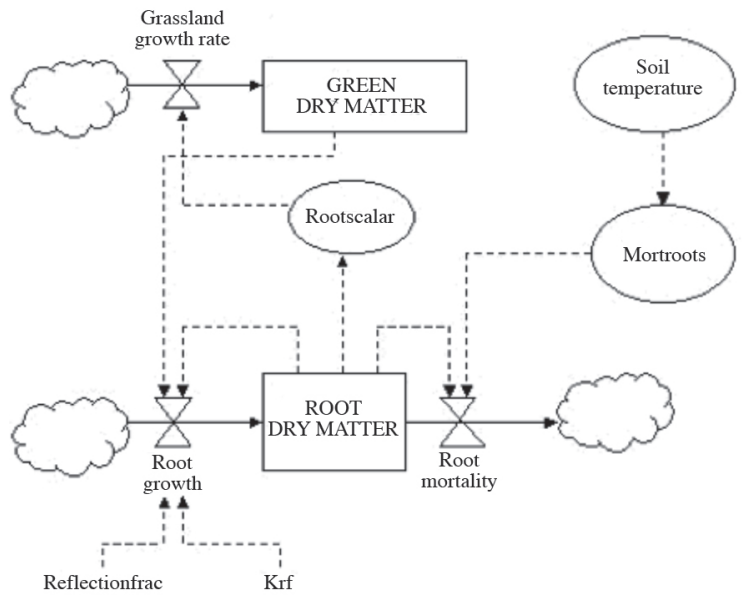

Figure 4. Simplified flow chart of root biomass growth and mortality.
TMORTroots $=$ mortroots $\times$ MSROOTS

$$
\text { mortroots }=0.03 \times\left(\frac{\text { tmd soil surf }}{30}\right) 0^{1.834}
$$

Thus, according to the number of roots at any given time, the generated root biomass effect on shoot growth is quantified by the variable ROOTSCALAR (Equation [23]).

Model behavior. This study evaluated model predictions as compared to real system data, that is, by comparing simulated values with actual values obtained from field experiments. Available experimental data only quantified total above-ground DM availability; therefore, only this variable was validated. The validation experiments considered three situations: DM accumulation of two naturalized grasslands and DM availability in a ryegrassclover pasture subjected to frequent cuts.

Behavior in the prediction of above-ground dry matter accumulation. In this case, two comparisons were made. We first compared above-ground DM data accumulation of grassland in a good condition dominated by Arrhenatherum elatius (L.) P. Beauv. ex J. Presl \& C. Presl subsp. bulbosum (Willd.) Schübl. \& G. Martens, Dactylis glomerata L., Holcus lanatus L., and Bromus valdivianus Phil. Secondly, we compared a grassland of a lower pasture condition where the dominant species was Agrostis capillaris L. (Ide, 1996). Weather data records for the experimental period (136 d, starting 15 September 1994) referred to precipitation, maximum and minimum temperatures, and solar radiation obtained from Isla Teja Weather Station at the Geosciences Institute, Universidad Austral de Chile (3947' S; 73¹5' W; 9 m a.s.l.) (Oyarzún, 2002, personal communication, Geosciences Institute, Universidad Austral de Chile). The soils where this trial took place belong to the Valdivia series with a silt loam surface texture, moderately deep, gently undulating, with a 5 to $8 \%$ slope, well-drained (Duric Hapludands), and classified as IIIe1 for soil use capacity. The water characteristics of the soil profile of this series are shown in Table 1. According to this information and to the criteria cited by Martínez de Azagra and Navarro (1995), this soil is classified as Type B (moderate permeability) and has a good hydrologic condition, thus a curve number equal to 61 (Campbell, 1997)

Eight parameters are needed to describe the characteristics of the physiology of grass growth. The values used and their sources are shown in Table 2.

Table 1. Soil water characteristics of Valdivia soil series (Duric

\begin{tabular}{|c|c|c|c|}
\hline $\begin{array}{l}\begin{array}{l}\text { Soil } \\
\text { depth }\end{array} \\
\end{array}$ & $\begin{array}{c}\text { Bulk } \\
\text { density }\end{array}$ & $\begin{array}{c}\text { Field } \\
\text { capacity }\end{array}$ & $\begin{array}{c}\text { Permanent } \\
\text { wilting point }\end{array}$ \\
\hline $\mathrm{cm}$ & $\mathrm{g} \mathrm{cm}^{-3}$ & 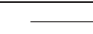 & - \\
\hline $0-19$ & 0.82 & 52.1 & 29.1 \\
\hline $19-34$ & 0.84 & 46.7 & 26.7 \\
\hline $34-55$ & 0.72 & 47.5 & 42.6 \\
\hline $55-80$ & 0.82 & 44.5 & 41.5 \\
\hline
\end{tabular}
Hapludands) used in model validation. 
Table 2. Physiological parameters used to predict mesophytic grassland growth.

\begin{tabular}{|c|c|c|}
\hline Parameter & Value & Reference \\
\hline Grassland potential growth, $\mathrm{kg} \mathrm{ha}^{-1} \mathrm{~d}^{1}$ & $\begin{array}{l}250 \text { for grassland in good condition } \\
185 \text { for grassland in fair condition }\end{array}$ & Dowle and Armstrong (1990) \\
\hline Critical soil water index & 0.8 & Wight and Hanks (1981) \\
\hline \multicolumn{3}{|l|}{ Temperatures for growth, ${ }^{\circ} \mathrm{C}$} \\
\hline threshold ${ }^{1}$ & 4.4-5.0 & Baker and Jung (1968) \\
\hline optimum $^{1}$ & $18.3-22.5$ & Brown et al. (1986) \\
\hline critical $^{1}$ & $32.2-35.0$ & CIREN (1982) \\
\hline Solar radiation coefficient & 0.25 & Own calculation \\
\hline Green dry matter $\left(\mathrm{kg} \mathrm{ha}^{-1}\right)$ associated with $50 \%$ grassland potential growth rate & 1500 & Rickert et al. (2000) \\
\hline Green dry matter $\left(\mathrm{kg} \mathrm{ha}^{-1}\right)$ associated with $50 \%$ grassland soil cover & 560 & Rickert et al. (2000) \\
\hline
\end{tabular}

${ }^{1}$ Lower values in the range are more suitable for temperate grasslands, while higher values are more suitable for ryegrass-white clover pasture.

The potential growth rate value of $250 \mathrm{~kg} \mathrm{ha}^{-1} \mathrm{~d}^{-1}$ was used to simulate grassland in good condition. In the case of simulating grassland dominated by A. capillaris, we used a value of $185 \mathrm{~kg} \mathrm{ha}^{-1} \mathrm{~d}^{-1}$ based on the fact that this species showed a specific growth rate equivalent to $74 \%$ of the mean calculated for the other species evaluated by Ide (1996). Root depth was set at $80 \mathrm{~cm}$ in both cases. At the start of the simulation, it was considered that the water soil level was equal to field capacity and initial total DM consisted of $100 \%$ green material, using a value of 2470 and $1992 \mathrm{~kg} \mathrm{ha}^{-1}$ to simulate grassland in good condition and dominated by A. capillaris, respectively. These values are provided by Ide (1996) for different grasslands evaluated on the same date. We assumed initial root biomass of $6000 \mathrm{~kg} \mathrm{ha}^{-1}$ and litter quantity of $100 \mathrm{~kg}$ $\mathrm{ha}^{-1}$ in both simulations.

Behavior in predicting above-ground dry matter availability under frequent cut management. In this validation, we compared simulated data of DM availability with those obtained in experiments conducted by Echeverría (1993) and Guzmán (1996) for a pasture of perennial ryegrass cv. Nui and Trifolium repens L. cv. Huia. These trials were conducted in consecutive seasons (1992-1993 and 1993-1994) on a site with similar characteristics to those described in previous validation tests. In these experiments, the pasture was cut every $30 \mathrm{~d}$ with clippers or when it reached a height of 30 $\mathrm{cm}$ and therefore leaving a residual height of $4 \mathrm{~cm}$. The experimental period was from 19 May 1992 to 20 April 1994. Weather data records for this period were obtained from the same source indicated for the DM accumulation experiment. The parameters required to describe the characteristics that define the physiology of pasture growth were the same as those indicated in Table 2, except for the value assigned to the potential growth rate, which we assumed to be $200 \mathrm{~kg} \mathrm{ha}^{-1} \mathrm{~d}^{-1}$. This value was chosen based on the fact that perennial ryegrass represented more than 90\% DM (Echeverría, 1993; Guzmán, 1996). Although this species has shown potential growth rates of $250 \mathrm{~kg} \mathrm{ha}^{-1} \mathrm{~d}^{-1}$ (Dowle and Armstrong, 1990) and given low soil $\mathrm{pH}$ (5.4-5.8), we assume that this factor, not considered in the model, affects grassland growth. For Lolium perenne, CIREN (1982) cites optimum $\mathrm{pH}$ ranges between 6.6 and 7.3 with $\mathrm{pH} 5.6$ as the minimum value tolerated by this species. The detrimental effect of $\mathrm{pH}$ could be explained by the possible toxicity effects due to increased $\mathrm{Al}$ exchange. This cation begins to increase its solubility as $\mathrm{pH}$ drops below the $\mathrm{pH}$ values measured in these soils (Gardner et al., 1985). Levels of $\mathrm{pH}$ were similar to those cited for this type of soil; Couto (1981) quoted relative yields between 42 and $72 \%$ of maximum yield for forage legumes and approximately $66 \%$ for forage grasses. There is evidence that the dominant native and naturalized species of mesophytic grasslands in the area would be better adapted to these soils than cultivated pasture species such as perennial ryegrass- $T$. repens pasture; the latter's performance is sometimes lower than those reported for grasslands (Balocchi and López, 2001). The potential growth rate value of $200 \mathrm{~kg} \mathrm{DM} \mathrm{ha}^{-1}$ $\mathrm{d}^{-1}$ seems reasonable according to van Heemst (1986) when cultivating forage grasses in temperate climates. Just as in the previous case, root depth was set at $80 \mathrm{~cm}$ (CIREN, 2003). It was considered at the beginning of the simulation (19 May 1992) that the water soil level was at field capacity and initial total DM was $2156 \mathrm{~kg} \mathrm{ha}^{-1}$, a value calculated from data measured by Echeverría (1993) on that date. Before the start of autumn grassland growth, DM was assumed to be composed of 70 and $30 \%$ green and dead material, respectively. Initial root biomass was assigned a value of $6000 \mathrm{~kg} \mathrm{ha}^{-1}$ and litter a value of $100 \mathrm{~kg} \mathrm{ha}^{-1}$.

In both validations, the degree of agreement between actual and simulated data was evaluated by calculating a linear regression between these values and then simultaneously performing the hypothesis of Student's statistical test for the intercept and slope of the calculated regression line. We also calculated the coefficient of determination of the regression line; moreover, we calculated the root mean squared error (RMSE) of prediction, expressing the result in absolute units as well as in percentage units regarding the mean value obtained in actual observations (Kaps and Lamberson, 2004).

\section{RESULTS AND DISCUSSION}

\section{Behavior prediction of above-ground dry matter accumulation}

Figure 5a shows the evolution of above-ground DM biomass accumulation for the natural grassland in good 
condition dominated by $A$. elatius subsp. bulbosum, $D$. glomerata, B. valdivianus, and H.lanatus. By matching the actual and simulated values, it was possible to calculate a highly significant $(\mathrm{P}<0.0001)$ linear regression equation, which exhibited a 0.976 coefficient of determination. This value would indicate that the model explains $97.6 \%$ of the variability of actual values. Furthermore, when analyzing the value of the slope and the intercept of the regression line that was calculated, it was observed that these coefficients were not significantly different from 1 and 0 , respectively $(\mathrm{P}>0.01)$. This indicates that the model has no large errors of over- or underestimation (Figure 5b).

By applying the RMSE calculation of the prediction to the measured and simulated data, we obtained a value of $709.2 \mathrm{~kg} \mathrm{DM} \mathrm{ha}^{-1}$ equivalent to $7.5 \%$ as compared to the mean of the actual values, thus confirming the appropriate predictive value of the model.

Figure $6 \mathrm{a}$ shows the evolution of above-ground DM biomass accumulation for grassland in fair condition dominated by $A$. capillaris. The regression equation obtained between actual and simulated data also exhibited a high statistical significance $(\mathrm{P}<0.00001)$ and a $96.2 \%$ coefficient of determination. As in the case of the simulation analysis of DM accumulation for natural grassland in good condition, the regression line was not statistically different ( $\mathrm{P}>0.001)$ to the line bisector (Figure 6b).

In this case, the RMSE prediction value was $594.8 \mathrm{~kg}$ $\mathrm{DM} \mathrm{ha}^{-1}$, equivalent to $8.3 \%$ as compared to the mean of the actual values.
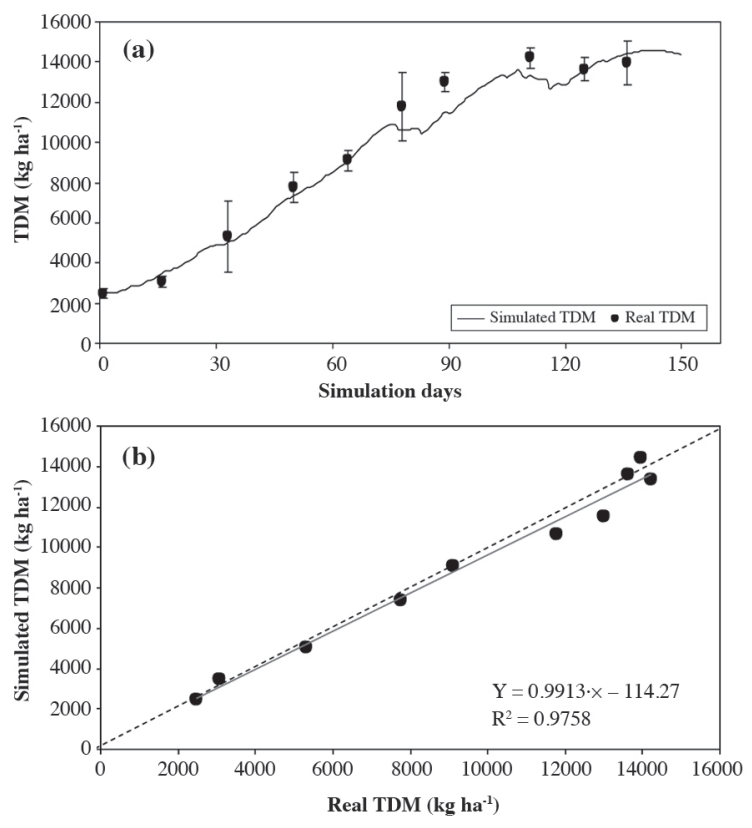

Figure 5. Evolution of above-ground dry matter accumulation (TDM) in mesophytic grassland dominated by Arrhenatherum elatius subsp. bulbosum, Dactylis glomerata, Bromus valdivianus, and Holcus lanatus. (a) Actual values $(\bullet)$ and simulated values $(-)$. Vertical bars above and/or below the point representing the actual observation indicates one standard deviation. (b) Regression equation between those values. Regression line $(-)$. Y = X Line (---).
Several published simulation models related to pasture growth with complex mathematical formulations (Nouvellon et al., 2000; Bonsemo and Bélanger, 2002; McCall and Bishop-Hurley, 2003) showed validation tests with similar results to those presented here. Therefore, the results obtained with this model are satisfactory, despite the simplicity of its equation formulation. The simple approach used in this work agrees with the one proposed by Skinner et al. (2009), which states that results can be obtained with simple models of the same order of magnitude as those obtained with more complex models.

Behavior in predicting above-ground dry matter availability under frequent cut management. Figure 7 a shows the evolution of DM above-ground biomass availability for the perennial ryegrass- $T$. repens pasture subjected to frequent cuts. There were major discrepancies between actual and simulated data. When relating these values, the calculated regression equation was highly significant $(\mathrm{P}<0.0001)$, but the coefficient of determination was $59.2 \%$. By analyzing the value of the slope and the intercept of the calculated regression line (Figure $7 b$ ), it could be seen that these ratios were not significantly different from the bisecting line $(\mathrm{Y}=$ $\mathrm{X})(\mathrm{P}>0.01)$. The biggest difference between the actual and simulated data caused the RMSE of prediction value to be approximately $742.8 \mathrm{~kg} \mathrm{DM} \mathrm{ha}^{-1}$, equivalent to $22.3 \%$ as compared to the mean of the actual values.
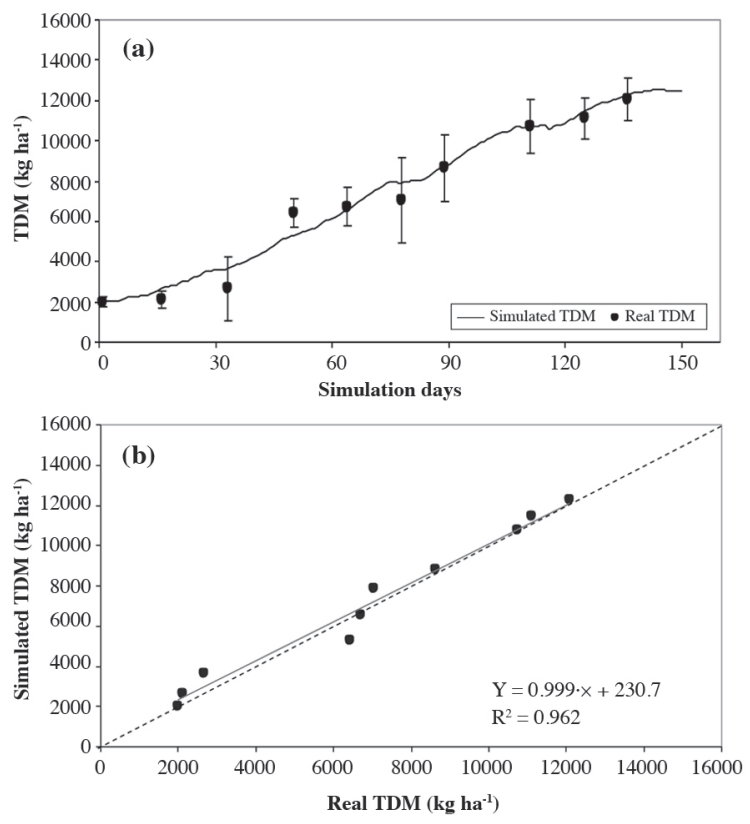

Figure 6. Evolution of above-ground dry matter accumulation (TDM) in mesophytic grassland dominated by Agrostis capillaris. (a) Actual values $(\bullet)$ and simulated values $(-)$. Vertical bars above and/or below the point representing the actual observation indicates one standard deviation. (b) Regression equation between those values. Regression line (-). Y $=\mathrm{X}$ Line (---). 

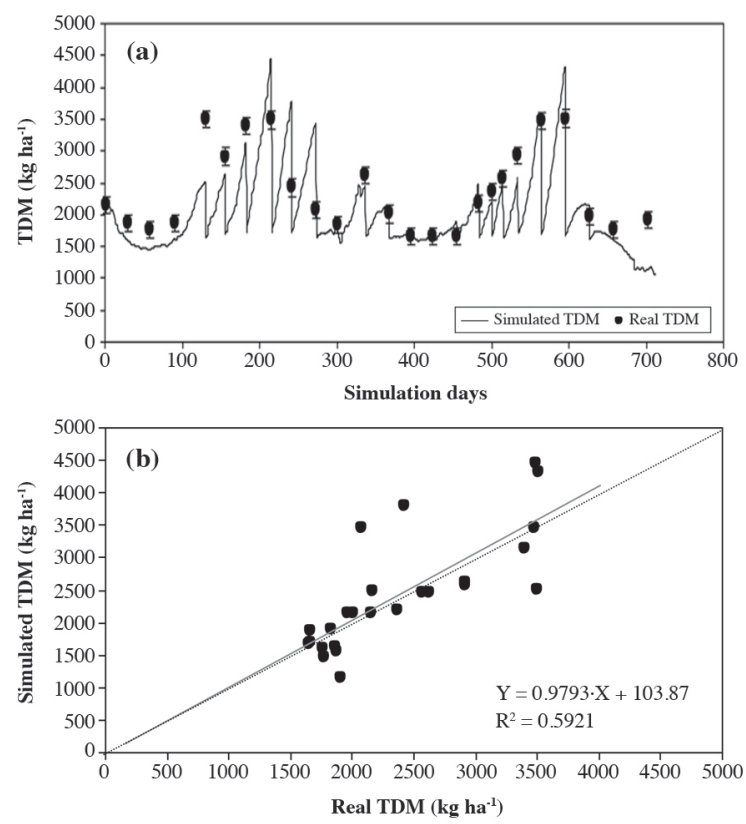

Figure 7. Evolution of above-ground dry matter accumulation (TDM) in mesophytic grassland dominated by Lolium perenne cv. Nui. (a) Actual values $(\bullet)$ and simulated values $(-)$. Vertical bars above and/or below the point representing the actual observation indicates one standard deviation. (b) Regression equation between those values. Regression line $(-) . Y=X$ Line (---).

Nevertheless, the value can be considered acceptable since field experiments conducted in grasslands commonly find variability values above $20 \%$ (Cangiano, 1996): it is a fact that measurement and growth performance in field conditions is subjected to numerous biases and errors (Mannetje, 2000). It is evident that the model's ability to predict DM accumulation under frequent cuts was lower because there are other sources of variation that are not considered, such as the effects of soluble carbohydrates that are mobilized from the roots to the above-ground biomass immediately after defoliation, which affects the grassland regrowth rate. This effect is not considered in the actual model and future versions should include it.

Future projections. In the area of validation, it is necessary to evaluate the ability of the model to simulate soil water dynamics and its accuracy to simulate the evolution of pasture with green and dead material DM through field experiments; if necessary, the assumptions associated with the mathematical formulation of the grassland senescence process should be revised.

It should be emphasized that the first version of this model does not explicitly consider the dynamic mobilization of carbohydrates from root reserves and its effect on the grassland regrowth rate, nor the effect of $\mathrm{N}$ soil level on the concentration of this element in plant tissue and its effect on pasture growth; therefore, one of the first priorities must be the development and incorporation of these factors to this model.

\section{CONCLUSIONS}

The information available in Chile allowed us to validate only some aspects related to above-ground DM availability. The simulation model presented here, despite its simplicity, realistically predicts DM accumulation of mesophytic perennial grasslands under non-limiting soil fertility levels, accounting for constraints imposed by soil water, temperature, solar radiation, and green DM availability on grassland growth rate.

As to predicting the effect of frequent defoliation, the predictive ability of the model decreases; however, the degree of fit between actual and simulated values is still within acceptable ranges. There are other factors that are probably related to the mobilization and use of reserves in regrowth which should be incorporated to improve the model's predictive ability.

Un modelo de simulación de pradera perenne mesofítica. Los pastizales son ecosistemas complejos y sus procesos se ven afectados por variables edáficas, meteorológicas y de manejo. En este contexto, los modelos dinámicos de simulación son útiles para la comprensión de estos procesos y diseñar estrategias de utilización de las praderas. El objetivo de este trabajo fue elaborar y validar un modelo de simulación de crecimiento de pastizales perennes, basado en variables de suelo y clima. En una primera aproximación se consideró que el suelo tenía adecuados niveles de fertilidad, por lo cual la disponibilidad de agua y el nivel de fitomasa fueron las principales variables que inciden sobre el crecimiento del pastizal. Se consideraron subrutinas de balance hídrico, crecimiento del pastizal y dinámica de biomasa radical. Las hipótesis referidas al funcionamiento del sistema fueron formuladas en un sistema de ecuaciones, el cual se resolvió numéricamente mediante un programa escrito en Visual Basic $®$. La validación del modelo se efectuó a través de la comparación estadística entre los valores de MS simulados y los valores reales obtenidos en experimentos realizados en la localidad de Valdivia (39 $47^{\circ}$, S; 73¹5' O; 9 m s.n.m.), donde se midió la acumulación de MS de praderas naturalizadas y en pasturas de ballica (Lolium perenne L.)-trébol blanco (Trifolium repens L.) sometidas a cortes frecuentes. Los datos de suelos, termopluviométricos, y de radiación solar fueron obtenidos de una estación meteorológica ubicada en la misma localidad. Los coeficientes de determinación entre los valores simulados y medidos en experimentos fueron más altos en el caso de la simulación de la acumulación de MS $\left(\mathrm{R}^{2}=98 \%\right)$. Cuando la pastura fue sometida a cortes frecuentes, el grado de ajuste del modelo fue menor $\left(\mathrm{R}^{2}\right.$ $=60 \%$ ), no obstante el modelo fue capaz de predecir la tendencia observada en los datos.

Palabras clave: modelos de simulación de praderas, pastizales mesofíticos. 


\section{LITERATURE CITED}

Ahumada, M.C., y L.Y. Faúndez. 2001. Guía descriptiva de las praderas naturales de Chile. 98 p. Ministerio de Agricultura, Servicio Agrícola y Ganadero (SAG), Departamento de Protección de los Recursos Naturales Renovables, Santiago, Chile.

Baker, B.S., and G.A. Jung. 1968. Effects of environmental conditions on the growth of four perennial grasses. I. Response to controlled temperature. Agronomy Journal 60:155-158.

Balocchi, L.O., y C.I. López. 2001. Rol de las especies pratenses nativas y naturalizadas en las praderas permanentes del sur de Chile. p. 285-299. XXVI Reunión Anual de la Sociedad Chilena de Producción Animal (SOCHIPA). Simposio Internacional en Producción Animal y Medio Ambiente, Santiago. 25-27 Julio 2001. Pontificia Universidad Católica de Chile, Facultad de Agronomía e Ingeniería Forestal, Santiago, Chile.

Birchman, J.S., and J. Hodgson. 1983. The influence of sward conditions on rates of herbage growth and senescence in mixed swards under continuous stocking management. Grass and Forage Science 38:323-331

Blackburn, H.D., and M.M. Kothmann. 1989. A forage dynamics model for use in range or pasture environments. Grass and Forage Science 44:283-294.

Bonsemo, H., and G. Bélanger. 2002. Timothy yield and nutritive value by the CATIMO model: I. Growth and nitrogen. Agronomy Journal 94:337-345.

Brown, W.F., L.E. Moser, and T.J. Klopfenstein. 1986. Development and validation of a dynamic model of growth and quality for cool season grasses. Agricultural Systems 20:37-52.

Campbell, G. 1997. Modelos simples de simulación para el manejo del riego. 216 p. Universidad de Concepción, Facultad de Ingeniería Agrícola, Chillán, Chile.

Cangiano, C.A. 1996. Métodos de medición de la fitomasa aérea. In C.A. Cangiano (ed.) Producción animal en pastoreo. Instituto Nacional de Tecnología Agropecuaria (INTA). Área de Producción Animal. Cap. 8. p. 117-128. INTA Balcarce, Buenos Aires, Argentina.

Castellaro G., G. Klee, y J. Chavarría. 2007. Un modelo de simulación de sistemas de engorda de bovinos a pastoreo. Chilean Journal of Agricultural Research 67:163-172.

Castellaro, G., L. Morales, M. Ahumada, and A. Barozzi. 2010. Simulation of dry matter productivity and water dynamics in a Chilean Patagonia range. Chilean Journal of Agricultural Research 70:417-427.

CIREN. 1982. Manual forrajeras y cultivos industriales. Requerimientos: Clima y suelo, especies y sus variedades. Publicación CIREN No 31.63 p. Centro de Información de Recursos Naturales (CIREN), Santiago, Chile.

CIREN. 2003. Estudio agrológico X Región. Descripciones de suelos, materiales y símbolos. Publicación $\mathrm{N}^{\mathrm{o}} 123.374$ p. Centro de Información de Recursos Naturales (CIREN), Santiago, Chile.

Couto, W. 1981. Soil pH and plant productivity. p. 71-83. In J.M. Rechcigl (ed.) Handbook of agricultural productivity. Volume I. Plant productivity. CRC Press, Boca Raton, Florida, USA

Dowle, K., and A.C. Armstrong. 1990. A model for investment appraisal of grassland drainage schemes on farms in the U.K. Agricultural Water Management 18:101-120.

Doyle, C.J., J.A. Baars, and A.C. Bywater. 1989. A simulation model of bull beef production under rotational grazing in the Waikato region of New Zealand. Agricultural Systems 31:247-278.

Echeverría, R. 1993. Efecto de la fertilización magnésica sobre el rendimiento y nivel de magnesio en una pradera permanente de la Décima Región. 53 p. Tesis Licenciado en Agronomía. Universidad Austral de Chile, Facultad Ciencias Agrarias, Valdivia, Chile.

Gardner, F.P., R.B. Pearce, and R.L. Mitchell. 1985. Physiology of crop plants. 327 p. Iowa State University Press, Ames, Iowa, USA.
Guzmán, C.F. 1996. Efecto de la fertilización magnésica, en un segundo año de aplicación, sobre el rendimiento y nivel de magnesio en una pradera permanente de la Décima Región. 64 p. Tesis Licenciado en Agronomía. Universidad Austral de Chile, Facultad de Ciencias Agrarias, Valdivia, Chile.

Hanson, J.D., J.W. Skiles, and W.J. Parton. 1988. A multi-species model for rangeland plants communities. Ecological Modelling 44:89-123.

Holechek, J.L., R.D. Pieper, and C.H. Herbel. 2001. Range management, principles and practices. $4^{\text {th }}$ ed. 587 p. Prentice Hall, Englewood Cliffs, New Jersey, USA.

Hudson, R.J., N. Donkor, and M. Okello. 2001. Pasture model for farmed wildlife. Project Completion Report. 25 p. Department of Renewable Resources, Faculty of Agriculture, Forestry and Home Economics, University of Alberta, Edmonton, Canada.

Ide, S.G. 1996. Caracterización fenológica y productiva de Arrhenatherum elatius ssp. bulbosus, Agrostis capillaris, Bromus valdivianus y Holcus lanatus en el Dominio Húmedo de Chile. 91 p. Tesis Licenciado en Agronomía. Universidad Austral de Chile, Facultad de Ciencias Agrarias, Valdivia, Chile.

Kaps, M., and W. Lamberson. 2004. Biostatistics for animal science. 445 p. CABI Publishing, Oxfordshire, UK.

Mannetje, L. t'. 2000. Measuring biomass of grassland vegetation. Chapter 7. p. 151-177. In Mannetje, L. t', and R.M. Jones (eds.) Field and laboratory methods for grassland and animal production research. CAB International, Wallingford, UK.

Martínez de Azagra, A., y H.J. Navarro. 1995. Hidrología forestal. El ciclo hidrológico. 286 p. Secretariado de Publicaciones, Universidad de Valladolid, Valladolid, España.

McCall, D.G., and G.J. Bishop-Hurley. 2003. A pasture growth model for use in a whole-farm dairy production model. Agricultural Systems 76:1183-1205.

Moir, J.L., D.R. Scotter, M.J. Hedley, and A.D. MacKay. 2000. A climate-driven, soil fertility dependent, pasture production model. New Zealand Journal of Agricultural Research 43:491-500.

Nouvellon, Y., S. Rambla, D. Lo Seen, M.S. Moran, J.P. Lhomme, A Bégué, et al. 2000. Modelling of daily fluxes of water and carbon from shortgrass steppes. Agricultural and Forest Meteorology 100:137-153.

Rickert, K.G., J.W. Stuth, and G.M. McKeon. 2000. Modelling pasture and animal production. Cap. 3. p. 29-66. In Mannetje, L.t', and R.M. Jones (eds.) Field and laboratory methods for grassland and animal production research. Wageningen Agricultural University, Wageningen, The Netherlands.

Skinner, R.H., M.S. Corson, and C.A. Rotz. 2009. Comparison of two pasture growth models of differing complexity. Agricultural Systems 99:35-43.

Smith, R.L., and T.M. Smith. 2000. Ecología $4^{\text {a }}$ ed. 642 p. AddisonWesley, Madrid, España.

Sumner, D.M., and J.M. Jacobs. 2005. Utility of PenmanMonteith, Priestley-Taylor, reference evapotranspiration, and pan evaporation methods to estimate pasture evapotranspiration. Journal of Hydrology 308:81-104.

Toro, P., A. Catrileo, C. Aguilar, and R. Vera. 2009. Modelling supplementation strategies for beef steer rearing and fattening systems in Southern Chile. Chilean Journal of Agricultural Research 69:207-213.

van Heemst, H.D.J. 1986. Physiological principles. p. 13-26. In van Keulen, H., and J. Wolf (eds.) Chapter 2.1. Modelling of agricultural production: Weather, soils and crops. Pudoc, Wageningen, The Netherlands.

Wight, J.R., and R.J. Hanks. 1981. A water-balance, climate model for range forage production. Journal of Range Management 34:307-311

Wight, J.R., C.L. Hanson, and K.R. Cooley. 1986. Modelling evapotranspiration from Sagebrush-Grass Rangeland. Journal of Range Management 39:81-85. 